\title{
Angela Murzagildina ${ }^{1}$, Elena Kulish ${ }^{1}$, Lyudmila Kuzina ${ }^{2}$, Roza Mudarisova², Sergei Kolesov ${ }^{2}$ and Gennady Zaikov ${ }^{3}$
}

\section{MODIFICATION OF CHITOSAN FILMS AS A WAY OF THEIR TRAN SPORT PROPERTIES REGULATION}

\author{
${ }^{1}$ The Bashkir State University \\ ${ }^{2}$ The Institute of Organic Chemistry of the Ufa Scientific Centre, Russian Academy of Science \\ Institute of Biochemical Physics, Russian Academy of Sciences
}

Received: October 28, 2011 / Revised: December 13, 2011 / Accepted: M ay 16, 2012

(c) Murzagildina A., Kulish E., Kuzina L., Mudarisova P., Kolesov S., Zaikov G., 2012

\begin{abstract}
Chitosan films obtained from solutions in acetic acid and containing the antibiotics - cephazolin and cephotoxim - have been investigated and the principal possibility of regulating their transport properties as regards the medicinal preparations release has been demonstrated. This regulation can be carried out by films thermal modification consisting in heating of the formed films at the temperature of about $393 \mathrm{~K}$ and their treatment with sodium dodecylsulphate solution.
\end{abstract}

Keywords: chitosan, polymer film, modification, antibiotic, sodium dodecylsulphate.

\section{Introduction}

Development of new methods of local treatment of wounds and burns using polymeric coatings with given properties is one of the rapidly developing trends in biomedicine. To provide a reliable medicinal effect the coatings must meet a number of special requirements including: atraumaticity, high sorption ability, protection from outside infecting, possibility of regulated release of medicinal substances, and others. The unique properties of aminopolysaccharide chitosan (ChT) - its biocombinability with organism tissues, bacteriostaticity, ability to enhance regenerative processes during wounds healing, biodegradability, excellent chelating capability, as well as its capacity for film formation determine the possibility of ChT using as film coatings of prolonged action for protection and treatment of surgical wounds and burns [1, 2]. The purpose of this investigation was to create medicinal chitosan films with regulated transport properties as regards immobilized medicinal preparation antibiotics cephazolin and cephotoxim.

\section{Experimental}

The objects of the investigation were the ChT specimen produced by the company "Bioprogress" (Russia) and obtained by acetic deacetylation of crab chitin (the degree of deacetylation is around $84 \%$ ), with $M n=80000$, and antibiotics of the cephalosporin series cephazolin (CPhZ) and cephotoxim (CPhT). ChT films were obtained by means of casting of polymer solution in acetic acid on the glass surface. The polymer mass concentration in the initial solution was $1 \mathrm{~g} / \mathrm{dl}$. Acetic acid concentration in the solution was $1 \mathrm{~g} / \mathrm{dl}$. Aqueous antibiotics solution was added to ChT solution immediately before films formation. The film thickness in all the experiments was maintained constant and equal to $0.1 \mathrm{~mm}$. The kinetics of $\mathrm{CPhZ}$ and $\mathrm{CPhT}$ release from film ChT specimens in aqueous medium was studied spectrophotometrically by optical density $A$ at $\lambda=270 \mathrm{~nm}$ and $\lambda=262 \mathrm{~nm}$, which corresponds to the maximum $\mathrm{CPhZ}$ and CPhT absorption respectively. To prevent solubility of the film in water it was subjected to thermal modification consisting in heating of the formed film at the temperature of about $393 \mathrm{~K}$ for $15-200 \mathrm{~min}$ [3] and it was treated with the solution of the surface-active substance - sodium dodecyl sulphate (SDS) with the concentration equal to $1-15 \mathrm{~g} / \mathrm{dl}$ (higher than CCM [4]). The content of the medicinal preparation in the film was $0.1 \mathrm{~mol} / \mathrm{mol} \mathrm{ChT}$. IR spectra of the specimens were recorded on the spectrometer "Specord-M 80" and "Shimadzu" ( $\mathrm{KBr}$ tablets, films) in the are of 700 $3600 \mathrm{~cm}^{-1}$. UV spectra of all specimens were taken in quarts dishes with the thickness of $1 \mathrm{~cm}$ relative to water on the spectrophotometer "Specord M-40" in the area of 220-350 nm. 


\section{Results and Discussion}

When developing material used for prolonged therapy one of the major problems determining the efficiency of the treatment is regulating the rate of transition of the medicinal substance to the wound. The ChT film obtained from acetic acid solutions contains in its salt form protoned $\mathrm{NH}_{3}{ }^{+}$groups and is well dissolved in water, therefore the medicinal substances are completely released during hour, which is comparable to the time of the film solution in water (Fig. 1, curve 1). In this case prolonged therapy is obviously not possible.

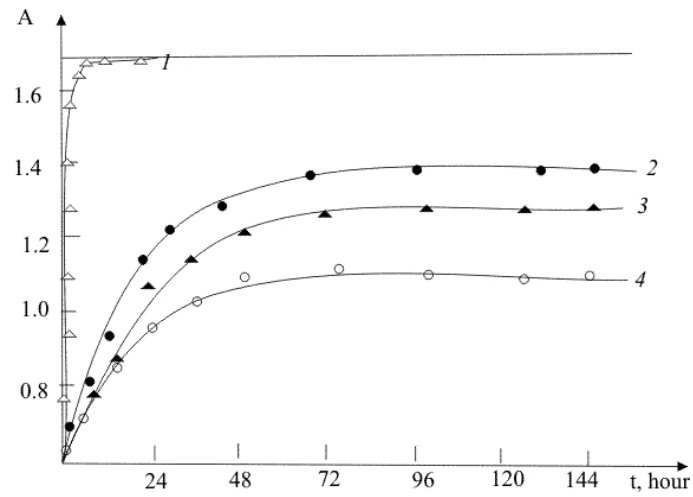

Fig. 1. Kinetic curve of $\mathrm{CPhZ}$ release from the film obtained from $1 \%$ acetic acid not subjected (1) and subjected to thermal modification during 15 (2), 30 (3) and 60 (4) minutes. The line shows the value of optical density corresponding to the $\mathrm{CPhZ}$ maximum content in the film equal to $0.1 \mathrm{~mol} / \mathrm{mol} \mathrm{ChT}$

The heat treatment of films is accompanied by removal of the acetic acid bound by the aminogroups and can in principle result in the amidation process with chitin units formation and, consequently, in the decrease in film affinity for water [5]. Presumably, the reactions taking place in the process of heat treatment are described by the following scheme:

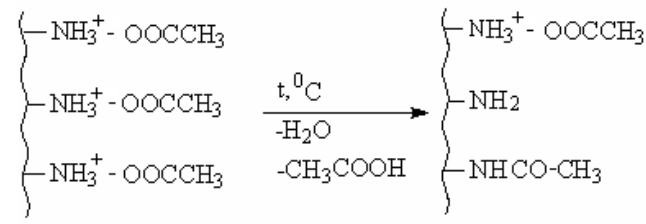

The fact of formation of amide groups in the heated films is confirmed by considerable strengthening of amide I band in IR-spectra in the area of $1630-1550 \mathrm{~cm}^{-1}$. Besides, one can observe the decrease in intensity of absorption of stretching vibrations of hydroxyl groups and the appearance of the shoulder characteristic of stretching vibrations of the aminogrops, in the area of 3500$3000 \mathrm{~cm}^{-1}$. These data testify to the fact that at heating there really occurs the increase both in the depth of the amidation reaction and in the splitting out of acetic acid.
Since the heat treatment of the films results in the loss of solubility in water the increased time of thermal treatment hinders the liberation of antibiotics from polymer matrix and, consequently, decreases the rate of medicinal substances release from the films. By varying the thermal treatment conditions it is possible to vary the transport properties of films as well. Indeed, as seen from Fig. 3, in the case of water-soluble films which are not subject to thermomodification the medicinal substance passes completely into solution during hour (curve 1), which is comparable to the time of the film solution in water.

Thermally modified films behave in a different way - there takes place considerable slowing down of the release of medicinal substance from the film. As seen from curves 2-4 in Fig. 1, during the first 10-20 h there occurs the release of medicinal preparation at a constant rate, then the process slows down and on the 7-10th day the concentration of the medicinal substance in the aqueous phase reaches its constant value. As this fact takes place, the longer the period of subjecting the film to thermal treatment, the lower the rate and the ultimate yield of antibiotic from the film (Fig. 2, Table 1).

Figs. 3 and 4 show the changes taking place in UVspectra of the film specimens ChT-CPhZ and ChT-CPhT at their thermal treatment.

As seen from the Figures, at increasing the time of films heating there occurs a significant displacement of the absorption band in the long-wave area by $30-40 \mathrm{~nm}$ and the change of its intensity, which testifies to the changes experienced by the polymer matrix. The heat treatment of individual medicinal compounds is not accompanied by the changes in their electron spectra.

The rate and the degree of the medicinal substances release from polymer matrix can also be regulated by modification of the obtained films by their treatment with the surface-active substance - sodium dodecyl sulphate. Just as in case of the heat treated films the release of medicinal substances from the films modified by SAS occurs considerably more slowly. In this case the longer the film was being treated with SAS and the higher its concentration, the lower the release rate and the ultimate antibiotic yield from the film (Table 1, Figs. 5 and 6). It is evident that the use of micellar SDS solution for films modification results in the formation of a strong waterinsoluble SAS polyelectrolitic complex. The surface of the modified film in this case represents a semi-penetrable membrane which allows water to penetrate into the film [6]. The increase of the inner layer volume leads to the surface membrane extension and the release of the medicinal substance from the film is facilitated. In this case, the higher the concentration of SDS used for modification and the longer the time of the film holding in SAS solution, the thicker the semi-penetrable membrane and the lower the medicinal preparation yield from the film. 


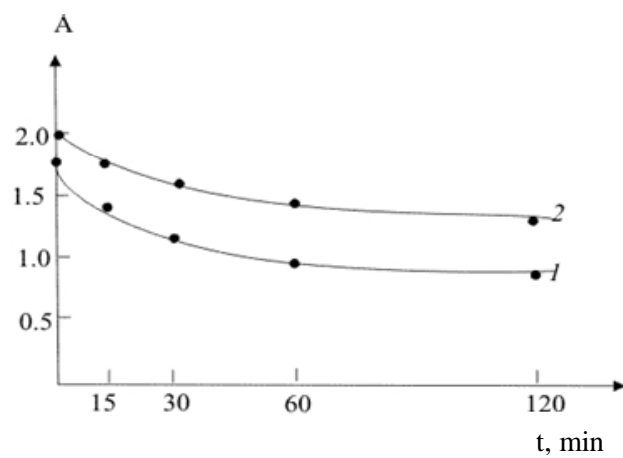

Fig. 2. Dependence of the value of solution optical density corresponding to the ultimate yield of $\mathrm{CPhZ}$ (1) and CPhT (2) from the films formed in $1 \%$ acetic acid, on the time of the film heat treatment

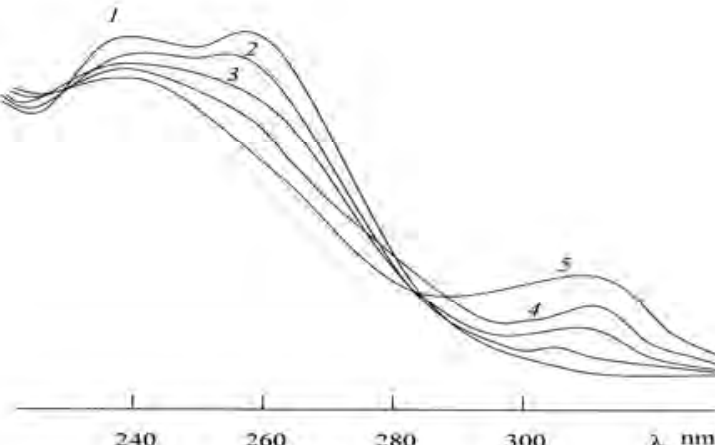

Fig. 3. UV-spectra of the initial film ChT-CPhT (1) and the films heated during 15 (2), 30 (3), 60 (4) and $120(5) \mathrm{min}$

Table 1

Influence of conditions of chitosan films obtaining and modification on transport properties of these films (initial rate and ultimate yield of antibiotics from the film)

\begin{tabular}{|c|c|c|c|c|c|}
\hline Antibiotic & \multicolumn{2}{|c|}{ Way of modification } & Treatment time, $\min$ & Initial rate, $Q^{*} / h$ & $\begin{array}{c}\text { Ultimate yield, } \\
Q^{*}\end{array}$ \\
\hline \multirow{9}{*}{$\mathrm{CPhZ}$} & \multirow{4}{*}{\multicolumn{2}{|c|}{ heat treatment }} & 15 & 2.80 & 80 \\
\hline & & & 30 & 2.55 & 76 \\
\hline & & & 60 & 2.20 & 65 \\
\hline & & & 120 & 2.0 & 57 \\
\hline & \multirow{5}{*}{$\begin{array}{l}\text { treatment with the } \\
\text { solution of SDS }\end{array}$} & \multirow{3}{*}{$5 \operatorname{mas} \%$} & 15 & 2.70 & 82 \\
\hline & & & 30 & 2.55 & 70 \\
\hline & & & 60 & 2.25 & 58 \\
\hline & & 10 mas $\%$ & 30 & 2.40 & 56 \\
\hline & & 15 mas $\%$ & 30 & 2.30 & 52 \\
\hline \multirow{9}{*}{$\mathrm{CPhT}$} & \multirow{4}{*}{\multicolumn{2}{|c|}{ heat treatment }} & 15 & 2.85 & 81 \\
\hline & & & 30 & 2.60 & 77 \\
\hline & & & 60 & 2.20 & 64 \\
\hline & & & 120 & 2.0 & 56 \\
\hline & \multirow{5}{*}{$\begin{array}{l}\text { treatment with the } \\
\text { solution of SDS }\end{array}$} & \multirow{3}{*}{5 mas $\%$} & 15 & 2.60 & 80 \\
\hline & & & 30 & 2.50 & 68 \\
\hline & & & 60 & 2.30 & 58 \\
\hline & & 10 mas $\%$ & 30 & 2.45 & 54 \\
\hline & & 15 mas \% & 30 & 2.25 & 50 \\
\hline
\end{tabular}

$Q^{*}-$ mas $\% \mathrm{CPhZ}$ of its initial amount introduced into the film

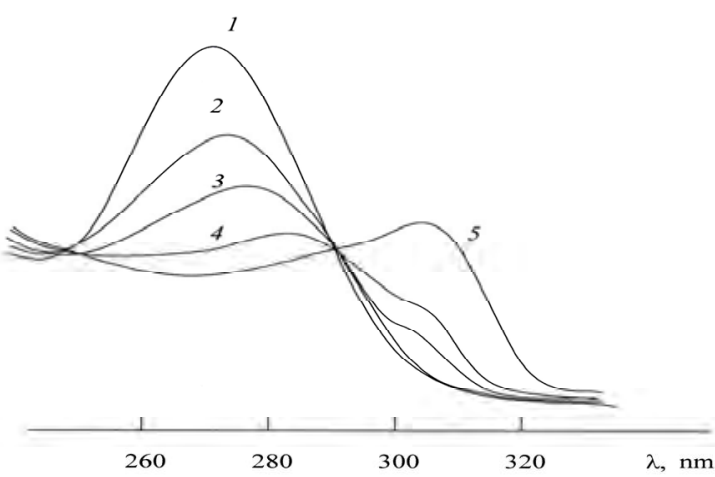

Fig. 4. UV-spectra of the initial film $\mathrm{ChT}-\mathrm{CPhZ}(1)$ and the films heated during 15 (2), 30 (3), 60 (4), and 120 (5) $\mathrm{min}$

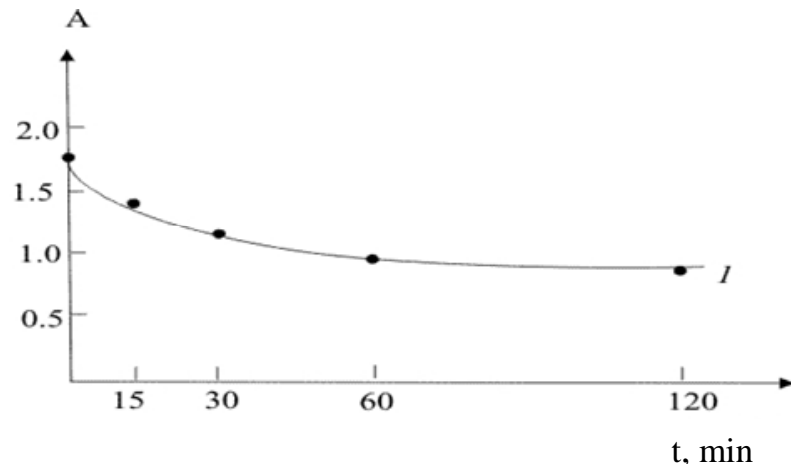

Fig. 5. Dependence of the solution optical density value corresponding to the ultimate $\mathrm{CPhZ}$ yield from the films formed in $1 \%$ acetic acid, on the time of films treating in $5 \%$ SDS solution 


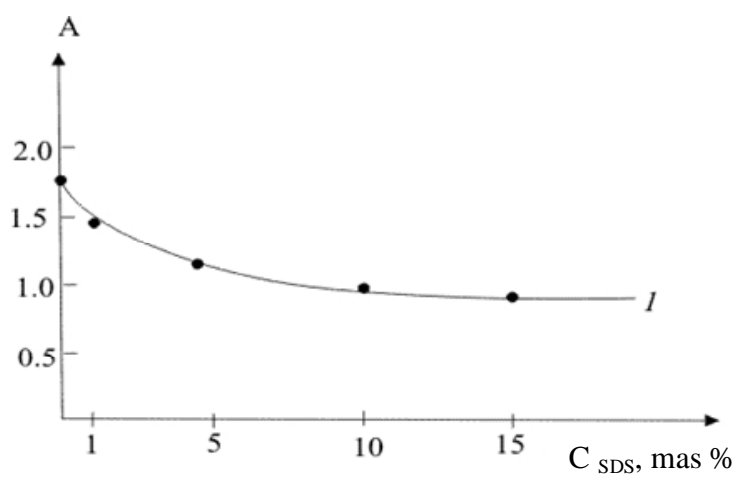

Thus, the ways allowing to regulate the degree and the rate of medicinal substance release from polymer matrix have been found.

\section{Conclusions}

For both investigated systems - chitosan- $\mathrm{CPhZ}$ and chitosan-CRhT it has been shown that the rate and the degree of medicinal preparations release from the films is determined by: i) time of film modification (time of heating of the film at the temperature of about $393 \mathrm{~K}$, or time of treatment with the solution of surface-active substances; ii) concentration of the used surface-active substances.

These factors predetermine the fundamental possibility of using ChT as film coverings of the prolonged action for protection and treatment of surgical wounds and burns.

\section{Acknowledgements}

The work has been carried out owing to the financial support of the RFFR (the Russian Fund of Fundamental Research) and Republic of Bashkortostan (grant r_povolzhye_a № 11-03-97016).
Fig. 6. The dependence of the solution optical density value corresponding to the ultimate $\mathrm{CPhZ}$ yield from the films formed in $1 \%$ acetic acid and treated with SAS solution for $30 \mathrm{~min}$, on SDS concentration

\section{References}

[1] Markvicheva E.: [in:] Scryabin K., Vikhoreva G. and Varlamov V. (Eds.), Chitin i Chitosan. Poluchenie, Svoistva, Primenenie. Nauka, Moskwa 2002, 315-326.

[2] Muzarelli R.: Chitin. Pergamon Press, Oxford 1977.

[3] Alexeev B. and Evmeenko G.:Vysokomol. Soed. A, 1999, 41, 1487.

[4] Abramzon A.: Poverhnostno-Aktivnye Veshchestva. Khimiya, Leningrad 1979.

[5] Zotcin M., Vikhorva G. and Kechekyan A.: Vysokomol. Soed. B, 2004, 46, 359.

[6] Rinodo M., Kildeeva N. and Babak V.: Ros.Khim. Zh., 2008, LII, 84.

\section{МОДИФІКОВАНІ ХІТОЗАНОВІ ПЛІВКИ 3 РЕГУЛЬОВАНИМИ ТРАНСПОРТНИМИ ВЛАСТИВОСТЯМИ}

Анотація. Досліджено плівки хітозану, отримані з розчинів в оцтовій кислоті, $i$ які містять антибіотики - церазолін $i$ цефатоксим. Показана принцииова можливість регулювання ӥх транспортних властивостей стосовно виходу лікарських препаратів. Встановлено, щчо регулювання здійснюється термічним модифікуванням плівок, а саме прогріванням сформованих плівок за температури близькій до $393 \mathrm{~K}$ i їх обробленням поверхневоактивною речовиною - додецилсульфатом натрію.

Ключові слова: хітозан, полімерна плівка, модифікаиія, антибіотик, додецилсульфат натрію. 